\title{
Alat Pengendali Sistem Kelistrikan Sepeda Motor Menggunakan Smartphone Berbasis Mikrokontroler Atmega328
}

\author{
Suharijanto ${ }^{1}$, Abdur Rohman Wakhid ${ }^{2}$ \\ 1) Program Studi Teknik Elektro Universitas Islam Lamongan \\ 2) Program Studi Teknik Elektro Universitas Islam Lamongan \\ email : suhar@gmail.com
}

\begin{abstract}
Abstrak- Pembuatan Alat Pengendali Sistem Kelistrikan Sepeda Motor menggunakan SmartPhone Berbasis Mikrokontroler ATmega328 adalah bertujuan membuat suatu alat pengendali sistem kelistrikan Sepeda Motor yang dapat mengendalikan sistem kelistrikan pada sepeda motor, dan dapat menjadi cadangan kunci motor dengan mudah, efesien, praktis dalam penggunaan untuk dapat meningkatkan kenyamanan dalam mengendalikan Sepeda Motor tanpa harus melalui Kunci Motor. Alat ini akan bekerja setelah perangkat bluetooth yang ada pada smartphone terhubung dengan modul bluetooth yang ada pada Alat Pengendali Sistem Kelistrikan Sepeda Motor Menggunakan SmartPhone. Metode yang digunakan dalam pembuatan Alat Pengendali Sistem Kelistrikan Sepeda Motor Menggunakan SmartPhone Berbais Mikrokontroler ini adalah tediri dari beberapa tahap yaitu Identifikasi Kebutuhan, Analisis Kebutuhan, Perancangan Perangkat Keras dan Perangkat Lunak, Pembuatan Alat, dan Pengujian Alat, Perangkat keras terdiri dari Sistem minimum ATmega328 sebagai pengendali utama, Smartphone android sebagai media pengendalian, Module bluetooth sebagai media penghubung. Berdasarkan hasil pengujian dapat disimpulkan bahwa Alat Pengendali Sistem Kelistrikan Sepeda Motor Menggunakan SmartPhone ini dapat bekerja sesuai dengan prinsip kerja yang dirancang.
\end{abstract}

Kata kunci: Smartphone, ATmega328, Bluetooth, Kelistrikan, Sepeda Motor.

\section{Pendahuluan}

Sepeda Motor adalah salah satu alat transportasi yang diciptakan oleh manusia, selain sepeda motor manusia juga menciptakan alat transportasi lain seperti mobil, dan kereta api. Penggunaan sepeda motor di Indonesia sangat populer karena harganya yang relatif murah, terjangkau untuk beberapa kalangan dan penggunaan bahan bakarnya irit serta biaya operasionalnya juga sangat rendah. hampir setiap hari manusia mengunakan alat transportasi jenis Sepeda Motor untuk pergi menuju tempat tujuan seperti kantor, sekolah, dan tempat kerja. Berdasarkan hal tersebut maka tidak jarang manusia lebih memilih kendaraan pribadi jenis sepeda motor untuk menuju tempat tujuan, karena sepeda motor lebih efektiv untuk digunakan menuju tempat tujuan. Sepeda motor mempunyai suatu komponen yang sangat penting untuk memulai menjalankan sepeda motor antara lain adalah kunci motor karena tanpa kunci motor sepeda motor tidak dapat di hidupkan dan di kendalikan oleh manusia.

\section{Metode Penelitian \\ Perancangan Alat \\ Dalam perancangan Alat Pengendali Sistem Kelistrikan Sepeda Motor Menggunakan}

SmartPhone ini menggunakan beberpa komponen-komponen. berikut adalah alat dan bahan yang di perlukan dalam pembuatan Alat Pengendali Sistem Kelistrikan Sepeda Motor Menggunakan SmartPhone :

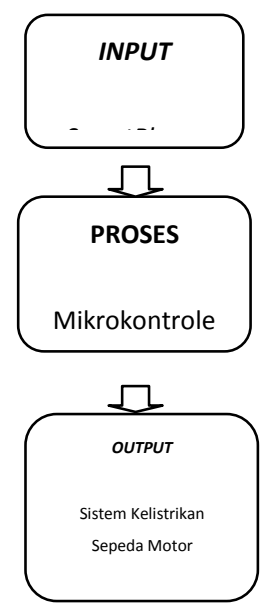

\section{Gambar 1. Blok Perencanaan Alat}

\section{Prinsip Kerja Alat}

Dalam sistem ini, user melakukan input dari aplikasi ArduDroid yang ada di perangkat Android. Input yang dipakai berupa input standar yaitu switchbutton. Data yang dimasukkan berupa data serial yang dikirim ke Arduino melalui bluetooth. Data yang dikirim dari Android akan diterima oleh modul Bluetooth hc- 
06 yang ada dalam sistem mikrokontroller. Dimana dalam hal ini mikrokontroller ialah ATmega328.

Data serial tersebut diterjemahkan oleh mikrokontroller menjadi data pararel. Data pararel yang dihasilkan oleh mikrokontroller diteruskan relay melalui indicator LED yang berfungsi untuk memastikan apakah ada yang salah pasang atau tidak. Jika sampai tahap ini proses berjalan lancar, kemudian relay akan meneruskan data yang digunakan untuk Mengendalikan kelistrikan Sepeda Motor seperti Starter, klapson, lampu riting, dan kontak kuncimotor. Led indikator berfungsi sebagai feedback. Yaitu apabila perangkat sepeda Motor hidup, led juga akan hidup. Begitu juga sebaliknya. Kondisi led saat hiup/ mati dimanfaatkan sebagai input ke Arduino. Data yang diperoleh dari Arduino tersebut dikirimkan kembali ke perangkat Android.



Gambar 2. Skema Rangkaian Alat

\section{Perancangan Perangkat Keras}

Untuk merancang Alat Pengendali Sistem Kelistrikan Sepeda Motor Menggunakan SmartPhone ini di butuhkan komponenkomponen sebagai berikut :

1. Sumber tegangan 12 Volt

2. Relay 5 volt

3. Transistor 7805

4. Transistor $\mathrm{S} 8050$

5. IC ATmega328

6. Modul Bluetooth hc-06

7. Resistor $10 \mathrm{k} \Omega$

8. Resisstor $22 \Omega$

9. Resistor $220 \Omega$

10.Resistor $2 \mathrm{k} 7 \Omega$

11.Tombol

12.Elco100 $\mu \mathrm{F} / 35 \mathrm{~V}$

13.Elco $100 \mu \mathrm{F} / 16 \mathrm{~V}$

14. Kristal $8 \mathrm{Mhz}$

\section{Perancangan Perangkat Lunak}

Perangkat lunak berfungsi untuk mengatur kinerja mikrokontroler ATmega328, dimana mikrokontroler Atmega328 merupakan otak sub sistem pengendali. Perangkat lunak direalisasikan mengacu pada sistem kerja alat, dimana program ini memungkinkan mikrokontroler untuk melakukan pengendalian seluruh sistem. Spesifikasi perangkat lunak yang akan dirancang adalah sebagai berikut :

1. Perangkat lunak diprogram melalui melalui alat bantu Arduino Uno.

2. Bahasa pemprograman yang di gunakan adalah bahasa $\mathrm{C}$

3. Program yang dibuat menggunakan instruksiinstruksi Mikrokontroler ATmega328.

4. Aplikasi yang digunakan untuk menuliskan program adalah aplikasi ARDUINO 1.0.6.

5. Aplikasi yang Digunakan di SmartPhone adalah aplikasi ArduDroid by TechBitar

\section{Rancangan Penelitian}

Dalam penelitian ini metode yang digunakan meliputi perancangan rangkaian elektronik, sistematis, agar diperoleh data dan informasi yang akurat. Mulai dari pengumpulan data, perancangan, pembuatan alat, pengujian, hingga analisis hasil akhir Alat.

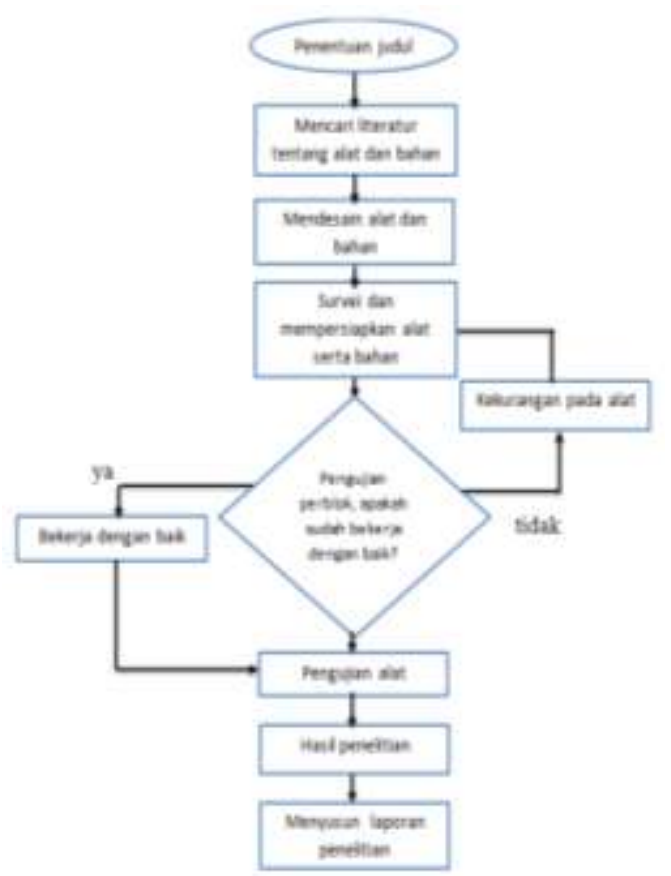

Gambar 3. Flow Chart pengerjaan penelitian 


\section{Hasil dan Pembahasan}

\section{Proses Kerja Alat Pengendali Sistem Kelistrikan Sepeda Motor Menggunakan SmartPhone}

Proses kerja Alat Pengendali Sistem Kelistrikan Sepeda Motor Menggunakan SmartPhone bisa di lihat pada diagram gambar di bawah ini:

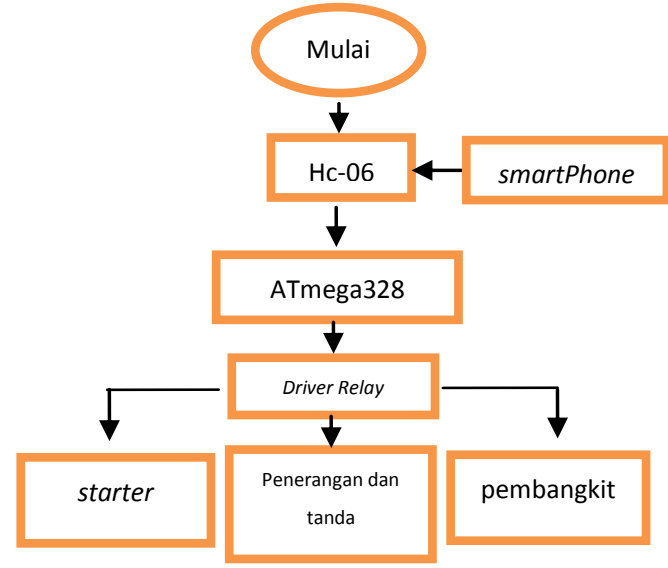

Gambar 8. Diagram kerja Alat Pengendali Sistem Kelistrikan Sepeda Motor Menggunakan SmartPhone

Alat Pengendali Sistem Kelistrikan Sepeda Motor Menggunakan SmartPhone ini bekerja berdasarkan perintah dari SmartPhone yang akan ditetrima oleh modul Bluetooth hc-06, modul Bluetooth ini akan memberikan data output kepada ATmega 328 yang sudah berisi program untuk kemudian di teruskan pada transistor dan relay, yaitu saat tombol pilihan dari SmartPhone diteken maka Atmega328 secara otomatis memberikan perintah output tegangan kepada transistor untuk menyalakan relay kemudian lampu indikator akan menyala dan sistem kelistrikan pada sepeda motor akan aktiv sesuai pilihan perintah dari SmartPhone.

\section{Pengujian Alat}

Pengujian Alat Pengendali Sistem Kelistrikan Sepeda Motor secara keseluruhan ini dilakukan dengan menggabungkan semua peralatan ke dalam sebuah sistem yang terintegrasi.Tujuannya untuk mengetahui bahwa rangkaian yang dirancang telah bekerja dengan baik.



Gambar 9. Alat Pengendali Sistem Kelistrikan Sepeda Motor Menggunakan SmartPhone

Pengujian Alat Pengendali Sisitem Kelistrikan Sepeda Motor Menggunakan SmartPhone dilakukan di ruang terbuka, dan diukur menggukan alat pengukur jarak manual, pengujian Alat Pengendali Sistem Kelistrikan Sepeda Motor dilakukan pada jam 15:27-17:22 tanggal 23 Juni 2016.

Table 1. Data Pengujian Jarak Jangkau Alat

\begin{tabular}{cccc}
\hline NO & JARAK & $\begin{array}{c}\text { TANPA } \\
\text { PENGHA } \\
\text { LANG }\end{array}$ & $\begin{array}{c}\text { DENGAN } \\
\text { PENGHALANG }\end{array}$ \\
\hline 1 & 5 Meter & On & On \\
\hline 2 & 10 Meter & On & On \\
\hline 3 & 15 Meter & On & On \\
\hline 4 & 20 Meter & On & On \\
\hline 5 & 25 Meter & On & On \\
\hline 6 & 30 Meter & On & On \\
\hline 7 & 35 Meter & On & On \\
\hline 8 & 40 Meter & On & Off \\
\hline 9 & 45 Meter & Off & Off \\
\hline 10 & 50 Meter & Off & Off
\end{tabular}

Tabel di atas adalah tabel hasil pengujian jarak Alat Pengendali Sistem Kelistrikan Sepeda Motor Menggunakan SmartPhone Berbasis Mikrokontroler ATmega328 yang dilakukan di ruang terbuka di luar rumah.

\section{Simpulan}

Cara perancangan dan membuatan Alat Pengendali Sistem Kelistrikan Sepeda Motor Menggunakan SmartPhone dapat menggunakan SmartPhone sebagai inputan perintah dan Modul Bluetooth sebagai penerima printah dari SmartPhone, dan Mikrokontroler ATmega328 sebagai prosessing.

Sistem kerja Alat Pengendali Sistem Kelistrikan Sepeda Motor Menggunakan SmartPhone ini jika Modul bluetooth Hc-06 menerima Perintah dari SmartPhone maka miktokontroler ATmega328 secara otomatis akan memberikan perintah output kepada kepada driver Relay. 
Jarak jangkauan ideal Alat Pengendali Sistem Kelistrikan Sepeda Motor Menggunakan SmartPhone adalah maksimal 35 Meter.

\section{Daftar Pustaka}

1. Atmel. Datasheet atmega48A 48A/88A/16A/328/328P. Atmel corporation .

2. Eko Krisyanto, M Sarwoko 2012. Sistem Keamanan Kendaraan Bermotor Berbasis Jaringan Seluler Menggunakan Sinyal DTMF". TELKOM University.

3. Muhamad Syahwil. 2013. Panduan Mudah Simulasi dan Praktek Mikrokontroler Arduino". Yogyakarta C.V Andi Offset.

4. Tim Skripsi, 2016, Pedoman Penulisan Skripsi, Fakultas Teknik Universitas Islam Lamongan.

5. http://www.blogspot.co.id

6. http://elektronika-dasar.web.id/teori-relayelektro-mekanik/

7. http://www.motorspotku.com

8. http://www.geraicerdas.com

9. http://www.vcc2gnd.com

10.https://www.wordpress.com

11.http://www.wikipedia.com 